Article

\title{
Bastardy in Butleigh: Illegitimacy, Genealogies and the Old Poor Law in Somerset, 1762-1834
}

\author{
Henry French $\mathbb{D}$ \\ Department of History, University of Exeter, Exeter EX4 4RJ, UK; H.French@exeter.ac.uk
}

Received: 29 November 2019; Accepted: 16 January 2020; Published: 22 January 2020

check for

updates

\begin{abstract}
Early academic histories of non-marital motherhood often focused on the minority of mothers who had several illegitimate children. Peter Laslett coined the phrase 'the bastardy prone sub-society' to describe them. More recent qualitative research has questioned the gendered perspectives underlying this label, and emphasised the complex, highly personal processes behind illegitimacy. By locating the social experience of illegitimacy, particularly multiple illegitimacy, within a broader genealogical and parochial context, this study tries to set the behaviour of particular individuals within a 'community' context in the late eighteenth and early nineteenth centuries. It places illegitimacy alongside pre-nuptial pregnancy within the sample parish, but also focuses on the majority of illegitimate births that fell under the administration of the parish and became 'bastardy' cases. It examines the parish's administrative responses, particularly its vigour in identifying and recovering money from putative fathers, and discusses the social circumstances of these fathers and mothers. It then goes on to reconstruct the inter-generational genealogy of a dense family network that linked several mothers and fathers of multiple illegitimate children. It highlights some significant and recurrent disparities of age and status within these family concentrations which lay beyond the limits of the courtship-centred model of illegitimacy.
\end{abstract}

Keywords: illegitimacy; motherhood; poverty; poor relief; eighteenth and nineteenth-century Britain

\section{Introduction}

Research into illegitimacy in pre-industrial England over the last half century has followed several successive historical approaches, and formulated two distinctive sets of conclusions. The pioneering parish studies of the Cambridge Group for the History of Population (CAMPOP) outlined the basic dynamics of illegitimacy over time (Oosterveen et al. 1980; Wrigley 1981; Wrigley et al. 1997). Studies by Laslett and Oosterveen, Levine, Wrightson and Levine, Richard Smith, Richard Adair and Martin Ingram, among many others, found that the incidence of illegitimate baptisms followed the general trend in population growth (Laslett 1977; Levine 1977; Levine and Wrightson 1980; Adair 1996; Ingram 1987). It was higher in the sixteenth century, when rates of population growth were higher. It fell through the seventeenth century, to a low point around 1700-1720, as population increases levelled off. It increased again in the latter half of the eighteenth century, as population levels rose rapidly once more. Similarly, the parents of illegitimate children were found to be roughly the same age as those of legitimate children through most of the period (Wrigley et al. 1997). This implied that most illegitimacy was the result of 'typical' patterns of sexual behaviour in courtship, by young, unmarried women and men, which just happened not to result in marriage. In this 'courtship intensity hypothesis', illegitimacy rates were treated as a function of the general propensity (and financial ability) of young people to marry. Research into the rate of bridal pregnancy showed that it averaged about 20 percent of all couples, but that it varied considerably by location and over time, and might exceed 40 percent of all brides. Similarly, although most CAMPOP research focused on relatively small rural parishes, where the (limited) numbers of illegitimate baptisms could fluctuate widely, Adair found that there were 
distinct regional patterns. Illegitimacy ratios were higher in parishes in northern and western England than in southern and eastern England. While subsequent research has pointed to the persistence into the late sixteenth century of customary 'spousals' conducted by extra-ecclesiastical 'hand-fasting' ceremonies in north-west England, some of these variations may have been due to the vigour of the archdiocesan 'disciplinary' machinery, or of the objections of religious reformers (McNabb 2006; Wrightson 1980).

Subsequent studies have not really challenged these basic demographic trends in illegitimacy in England, although they have emphasised regional variation, and the fact that other trends and explanations might apply in Wales, industrialising towns or the metropolis. Some have taken issue with the insistence by these early demographic studies on the existence of sub-groups of women who gave birth to more than one illegitimate child, sometimes to the same denominated father, and sometimes to different named fathers. Laslett termed this group, 'the bastardy-prone sub-society', and other studies (notably Smith's and Adair's) referred to them by the short-hand 'repeaters' (Laslett 1980; Levine 1977; Oosterveen et al. 1980). While these demographic studies tended to treat such a group as a puzzling statistical anomaly, the language used to describe it implied that such people were aware of their identity, or had even made consciously 'non-conformist' choices (Reay 1990). When viewed in the context of the now-superseded research of Edward Shorter and Gerald Quaife, the identification of this 'sub-society' carried connotations of a bucolic 'permissive society' in early modern England (Shorter 1971; Quaife 1979). While these ideas quickly collapsed under the weight of evidence to the contrary, demographic approaches failed to produce clear explanations, and tended instead to infer motives about 'conformity' or 'non-conformity' from the trends alone (Levine 1977; Oosterveen et al. 1980). The most notable exception was Reay's detailed analysis of the Kentish settlements of Dunkirk and Hernhill, which placed the mothers and fathers of illegitimate children in the context of familial groupings (and some very illuminating mid-late nineteenth-century Petty Sessions evidence), and dismissed the notion of a 'sub-society' by identifying concealed long-term non-marital relationships, as well as exploitative (and repetitive) sexual behaviour among some men (Reay 1990).

More recent research has moved to the detailed qualitative investigation of the circumstances surrounding illegitimate births, particularly through the records of ecclesiastical courts, parish 'bastardy examinations' and working-class autobiographies. These have complicated the simple narratives that cast illegitimacy as a function either of 'marriage frustrated', or the 'bastardy-prone sub-society'. Instead, studies by Rebecca Probert, Tanya Evans, Thomas Nutt, Alanna Tomkins, Samantha Williams, Emma Griffin, Joanne Bailey, Angela Muir and Katie Barclay, have shown that the baptism of a child outside marriage was the outcome of complex social processes (Probert 2014; Evans 2005; Nutt 2005; Tomkins 2015; Williams 2014; Griffin 2013; Bailey 2014; Muir 2018; Barclay 2019). Parents might not marry because mobility, unemployment or war prevented it, or even because of passing suspicions, jealousies or gossip. The pregnancy might have resulted from coercion or exploitation, particularly between employers and servants. Some illegitimate children were the products of stable, but bigamous relationships, in a society where divorce was all-but impossible and within working-class communities where illegitimacy was tolerated. As Nutt's research on the examinations of putative fathers has shown, it may also have resulted from less stable patterns of 'serial monogamy', or of adulterous relationships (Nutt 2005). In general, Probert has noted that cohabitation outside marriage was relatively rare, although it might account for 10 percent or more of 'bastardy examinations' in the metropolis (Probert 2014). Detailed qualitative case-studies have provided little documentary support for the idea of a consciously deviant 'sub-society', even if research into masculinities has noted that transgressive heterosexual behaviour was valorised among young unmarried men, and that toleration of it complicated or undermined prosecutions for rape or sexual abuse (Shepard 2003; Kelly 2006; Statt 1995; Chaytor 1995; Bailey 2006; McEwan 2011). By recovering the 'micro-politics' of the personal circumstances of the mothers and fathers of illegitimate children, and by setting these within more sophisticated, and problematised, understandings of gender, these studies have largely, and justifiably, dissolved the boundaries of the 'sub-society'. 
Yet, interpretations that focus primarily on the individual experiences of illegitimacy risk losing some of the wider social perspectives offered by earlier demographic studies. It remains important to view these experiences and behaviours in the context of social inclusion and exclusion, particularly within the administrative parish as a site of administration, provision, and stigmatisation. While there were many individual, personal reasons why children were born outside marriage, as Samantha Williams has shown recently for London, such parents and children experienced 'bastardy' as a constructed administrative and normative category within the social space of the parish, the workhouse, or the 'community' of neighbours, ratepayers, and officers (Williams 2018). Research by King, in particular, has drawn attention back to the stubborn statistical observation that there were concentrations of illegitimacy within families in particular parishes. He found that 'almost two-fifths of all bastards born to women in three of the four parishes are part of a multiple illegitimacy experience' (King 2005). King set these demographic findings in the context of pauper letters to overseers, and suggested that there may have been a difference in the attitudes expressed by mothers of one illegitimate child, compared to those who had borne several, or who came from a family in which illegitimacy was more frequent. The latter 'wrote more frequently and assertively' to overseers, which he suggests may indicate a degree of cultural and moral separation from the wider community. Williams' recent work on shame and illegitimacy enjoins a degree of caution here, as she illustrates how it remains very difficult to disentangle the attitudes of the mothers and fathers of illegitimate children from rhetorical tactics they needed to employ to secure assistance from the parish (Williams 2018). Even so, King's research highlights that illegitimacy recurred more frequently in some families than in others, in ways that did not depend wholly on chance.

By locating the social experience of illegitimacy, particularly multiple illegitimacy, within a broader genealogical and parochial context, this study tries to set the behaviour of particular individuals within a 'community' context in the late eighteenth and early nineteenth centuries. It places illegitimacy alongside pre-nuptial pregnancy within the sample parish, but also focuses on the majority of illegitimate births that fell under the administration of the parish and became 'bastardy' cases. It examines the parish's administrative responses, particularly its vigour in identifying and recovering money from putative fathers, and discusses the social circumstances of these fathers and mothers. It then goes on to reconstruct the inter-generational genealogy of a dense family network that linked several mothers and fathers of multiple illegitimate children. It highlights some significant and recurrent disparities of age and status within these family concentrations which lay beyond the limits of the courtship-centred model of illegitimacy.

\section{The Study Community}

This research focuses on a micro-analysis of the Somerset village of Butleigh, between 1762 and the end of the Old Poor Law in 1834, to explore these complex issues in depth. It utilises a database of all poor relief recipients created using parish registers and the overseers' accounts transcribed on the Butleigh.org website by Mr. R. C. Senior [http:/butleigh.org/]. The records consulted here include Butleigh Baptism Registers, 1714-1812, 1813-45; Marriage Register, 1714-1837; Burial Registers 1714-1812, 1813-37; Butleigh Overseers' Accounts, 1762-1804, 1805-25 and 1825-36, plus the family histories listed in http://butleigh.org/butleighpeople/butleighpeople.html. The latter have been checked (and occasionally modified) by reference to evidence about family structures in the overseers' accounts. The database of overseers' payments details 51,238 payments to 958 recipients between 1762 and 1834 . This article is based on 8776 payments to mothers of illegitimate children in this period, plus 433 periodic payments by putative fathers, $1762-1828$.

Butleigh is located three miles south-east of the market-centre of Glastonbury in central Somerset. Its total population remained below 1000 inhabitants throughout the period, but rose significantly, from 694 residents in 1801 to a peak of 952 in 1831. It was largely under the control of landed families, and primarily agrarian in character. The parish was oblong in shape, with the two longest sides on its east and west edges. It was not a nucleated settlement, and was split between Butleigh village 
and manor in the southern half of the parish, owned by the Grenville and Neville-Grenville families, and the detached hamlet of Butleigh Wootton in the north-west corner, owned by the Hood family (Siraut et al. 2006). In the eighteenth century, Butleigh village possessed approximately 50 houses, Butleigh Wootton had approximately 20, and there were a further 30 cottages and farms scattered outside these two focal points. There was a stone quarry in the south west of the parish, and nearly 400 ac. of woodland, offering some non-agrarian male employment. Agriculture was primarily arable, but the village possessed pasture rights on the marshes of Sedgemoor to the west of the parish, which were enclosed in 1796 (SALS DD/S/BT/3/9 1795).

In the 1841 Census, 166 out of 394 households (or 42 percent) were engaged in agricultural employment of all kinds, including farmers. However, in addition to the usual spread of rural crafts (blacksmiths, carpenters, coopers, and thatchers) there were also 28 stone cutters or stone masons in the quarry and 10 shoemakers. By this time, the latter may have been doing out-work for the Clark brothers at Street, which was located only 2 miles north of Butleigh (Sutton 1979). In the 1828 Tithe Award, only 53 out of 134 occupiers (40 percent) owned land in Butleigh (SALS DD/S/BT/3/12/12 1828; SALS D/P Butl/13/1/3 1826-7). Labourers were not entirely excluded from landownership, but their holdings were tiny. 24 persons can be identified as 'labourers' or 'agricultural labourers' among the holders of land in 1828. Only 5 owned their properties, 2 owned and rented and 19 only rented them. Across the group the mean area owned or rented was just 0.93 acres ( 0.4 hectares). These units were far too small to offer a full subsistence livelihood, but they may have provided income supplements-supporting a cow, or enabling cultivation of a large area of garden produce. Most other village smallholders were construction craftsmen (such as carpenters, thatchers, or masons), clothes producers (tailors and shoemakers) or food processors (butchers, bakers, or brewers). Although a minority of farmers owned part or all of their properties, landownership was dominated by the local elite- the Hon. Rev. George Neville Grenville of Butleigh Court and Mrs. Elizabeth Hood of Butleigh Wootton, whose estates comprised 82 percent of the land area of the parish. In Butleigh, therefore, although a few labourers and craftsmen owned or rented houses with garden-plots, the 'tripartite' division between large landowners, tenant-farmers and landless labourers was established very clearly by the 1820 s.

\section{Poverty in Butleigh and the Maintenance of Illegitimate Children}

Although problems of poverty increased in the village, particularly in the 1790s, the worst years were in the harvest failures around 1800-1801, rather than the immediate post-war years of 1816-1820, as in some other parts of southern England. Returns made to Parliament about poor relief levels in Somerset showed that although the costs of relief for the county as a whole more-than doubled between 1783-1785 and the early nineteenth century, rises in Butleigh were consistently lower than this, at 140 to 150 percent of the level in the mid-1780s (UK P.P. 1818, XIX.1; UK P.P. 1822, XV, 1; UK P.P. 1825, IV, 39; UK P.P. 1830-1, XI. 227; UK P.P. 1835, XLVII. 185). Figure 1 shows that although after 1770 the annual costs of poor relief (adjusted for inflation) were double those of the period 1700-1730, they fell back to their usual level after the crisis of 1800-1801. After another peak in the early 1820s, annual relief expenditure in the village only began to a new level in the last years of the Old Poor Law.

The size of the population receiving relief in Butleigh also grew through the period under observation. Figure 2 displays two groups of recipients. The solid line represents the 958 recipients named in the overseers' accounts through the period, whose unique identity has been established in the project database. The broken line is slightly more speculative, but indicates the number of live children under the age of 15 born to these identified recipients, and likely to be co-resident with them. This represents an absolute maximum, because it is probable that some children were not resident, and we have no parish censuses to illustrate the actual composition of these households. However, it suggests that if the total village population in 1801 was 694, as many as 233 (or 33 percent) of the village's residents lived in households which received some relief that year. Proportions such as these may not have been uncommon in southern England at this time (French 2013). 


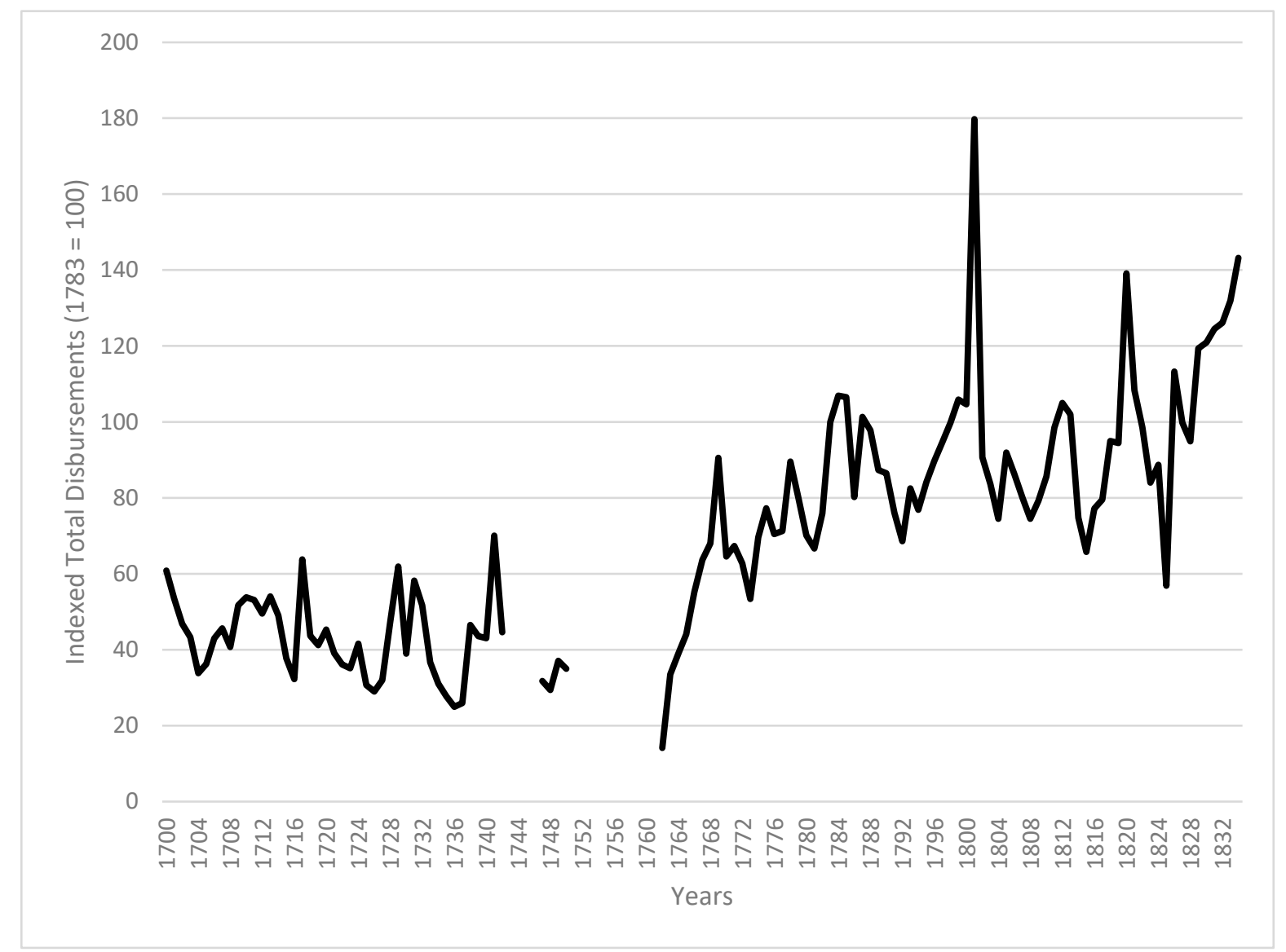

Figure 1. Total Overseers' Disbursements in Butleigh, Somerset, 1700-1835: at constant (£1860-1869) Prices Indexed Where $1783=100$. (see Clark 2007).

As will be shown below, a significant proportion of this expenditure was directed towards illegitimate children and their mothers. The number of baptisms of illegitimate children varied considerably from year to year in Butleigh, but with a series of clear peaks. Figure 3 illustrates the illegitimacy ratio per decade in Butleigh. Unfortunately, there are gaps in the baptism registers, so the figure also presents the illegitimacy ratio calculated in years without obvious defective registration. Peaks occurred in the years between 1760 and 1779, and 1800 and 1819, but also (to a lesser extent) between 1740 and 1749, and the proportion of illegitimate baptisms rose consistently after 1830. These took the illegitimacy ratio to higher levels than those found in many of the CAMPOP surveys, and comparable to King's Lancashire parishes (King 2005; Laslett 1977; Oosterveen et al. 1980). As will be shown below, while the incidence of sharp increases in specific years may be due to 'random' influences (the behaviour of particular individuals), the timing of the more sustained increases in illegitimacy appears to coincide with periods of significant socio-economic stress, particularly after 1800 . Although the absolute numbers of illegitimate baptisms in any given year were usually low (normally less than one per annum on average before the 1750s, and between 1.0 and 1.6 per annum thereafter, rising above 2 per annum in the 1770s and 1810s), the costs associated with the care and provision of these young children and their mothers stretched over years, and accumulated to significant amounts. Table 1 shows that a substantial proportion of these illegitimate children were born to mothers who had more than one child outside marriage, as many as 30 percent across the period. Gaps in the registration of all baptisms undermine the reliability of these figures, and some illegitimate children recorded in the overseers' accounts are absent, but the proportions in Butleigh appear similar to King's attribution of 'two-fifths' of all illegitimate baptisms to mothers of more than one child in his Lancashire parishes. 


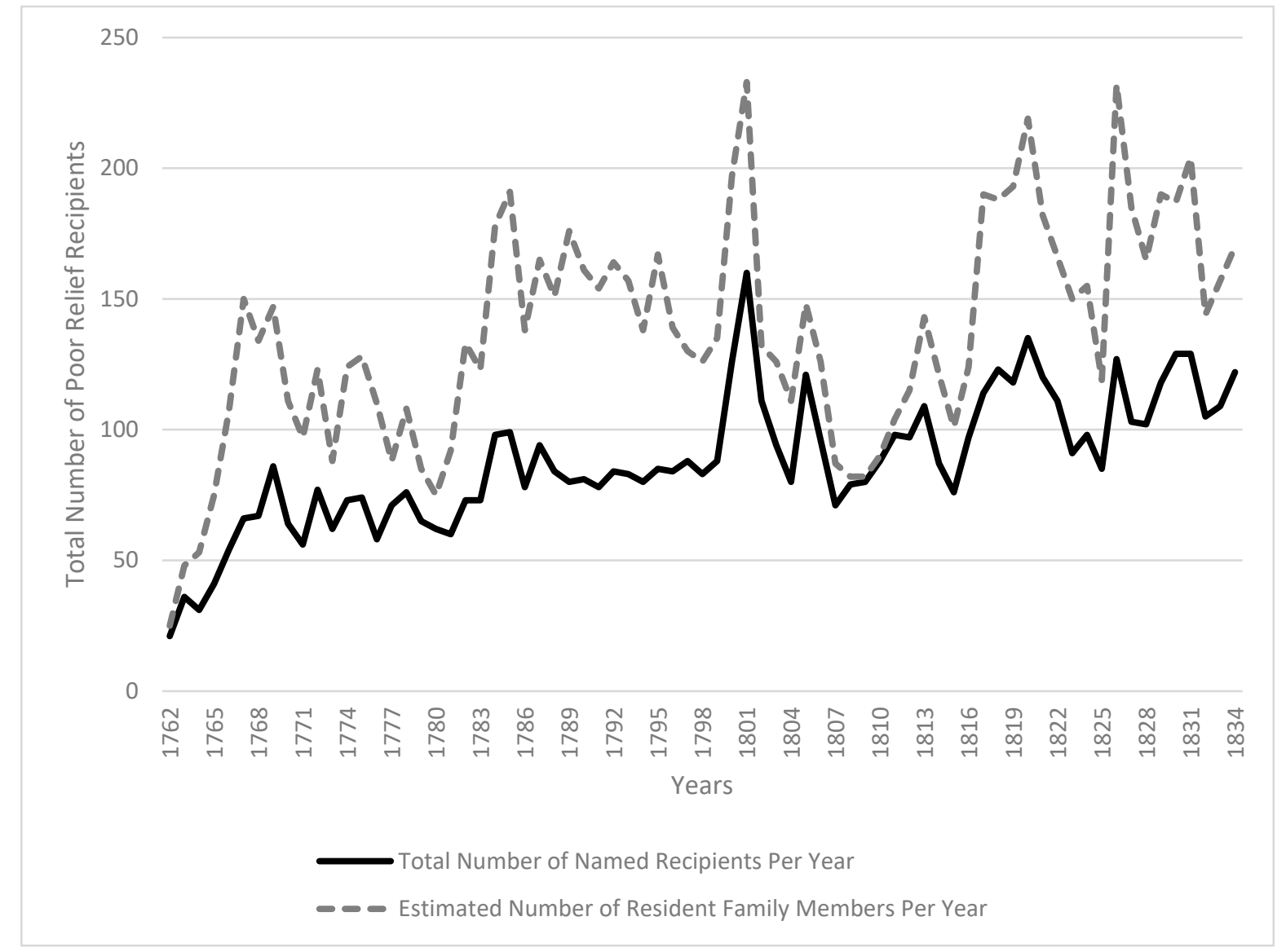

Figure 2. Total Number of Named Poor Relief Recipients Compared to Estimated Family Size Associated with Named Recipients, Butleigh Somerset, 1762-1834.

Table 1. Numbers and Proportion of Illegitimate Baptisms in Butleigh to Mothers of One and More than One Illegitimate Child.

\begin{tabular}{cccc}
\hline 20 Year Period & $\mathbf{> 1}$ Baptism Per Mother & All Illegit Baptisms & $\mathbf{\%}>\mathbf{1}$ \\
\hline $1710-1729$ & 2 & 6 & 33.3 \\
$1720-1749$ & 4 & 14 & 28.6 \\
$1750-1769$ & 5 & 25 & 20.0 \\
$1770-1789$ & 19 & 40 & 47.5 \\
$1790-1809$ & 10 & 22 & 45.5 \\
$1810-1829$ & 9 & 33 & 27.3 \\
$1830-1849$ & 0 & 16 & 0.0 \\
\hline & 49 & 156 & 31.4 \\
\hline
\end{tabular}

Figure 4 compares the total proportion of relief paid to the mothers of illegitimate children and to the children themselves, with the percentage of recorded baptisms of illegitimate children. Unsurprisingly, it shows that proportion of total relief devoted to these recipients increased after each peak in illegitimate baptisms within the parish, particularly between 1780 and 1790, 1800 and 1810 and 1816 and 1826. In the early 1780s and in the decade after 1816, fully 20 percent of the parish's total poor relief expenditure was paid to these mothers and children. The parish incurred costs of $£ 30$ to $£ 50$ per annum on relief directed to mothers and their illegitimate children after 1800 . However, this did not reflect lax administration or any willingness to turn a blind eye to the issue. In fact, the parish authorities pursued and stigmatised parents of illegitimate children, creating a social legacy that these children found difficult to escape. The overseers' accounts demonstrate that parish officers were assiduous in tracing the fathers, arresting them, bringing them before the JPs to administer filiation 
bonds, and then in chasing them again when they were slow to pay. For example, after Joseph Godfrey fathered Ann Wheeler's son, Joseph, in 1783 the overseers took out warrants to obtain payment from him that year, and in 1785, 1787 and 1788. In 1787 the overseers had him arrested for non-payment and opposed his discharge at the Quarter Sessions. The following year, the overseers travelled to Somerton and Walton to obtain witness statements on oath against him, and to Glastonbury, to get the approval of the mayor. Godfrey was compelled to pay maintenance for Joseph until March 1796.

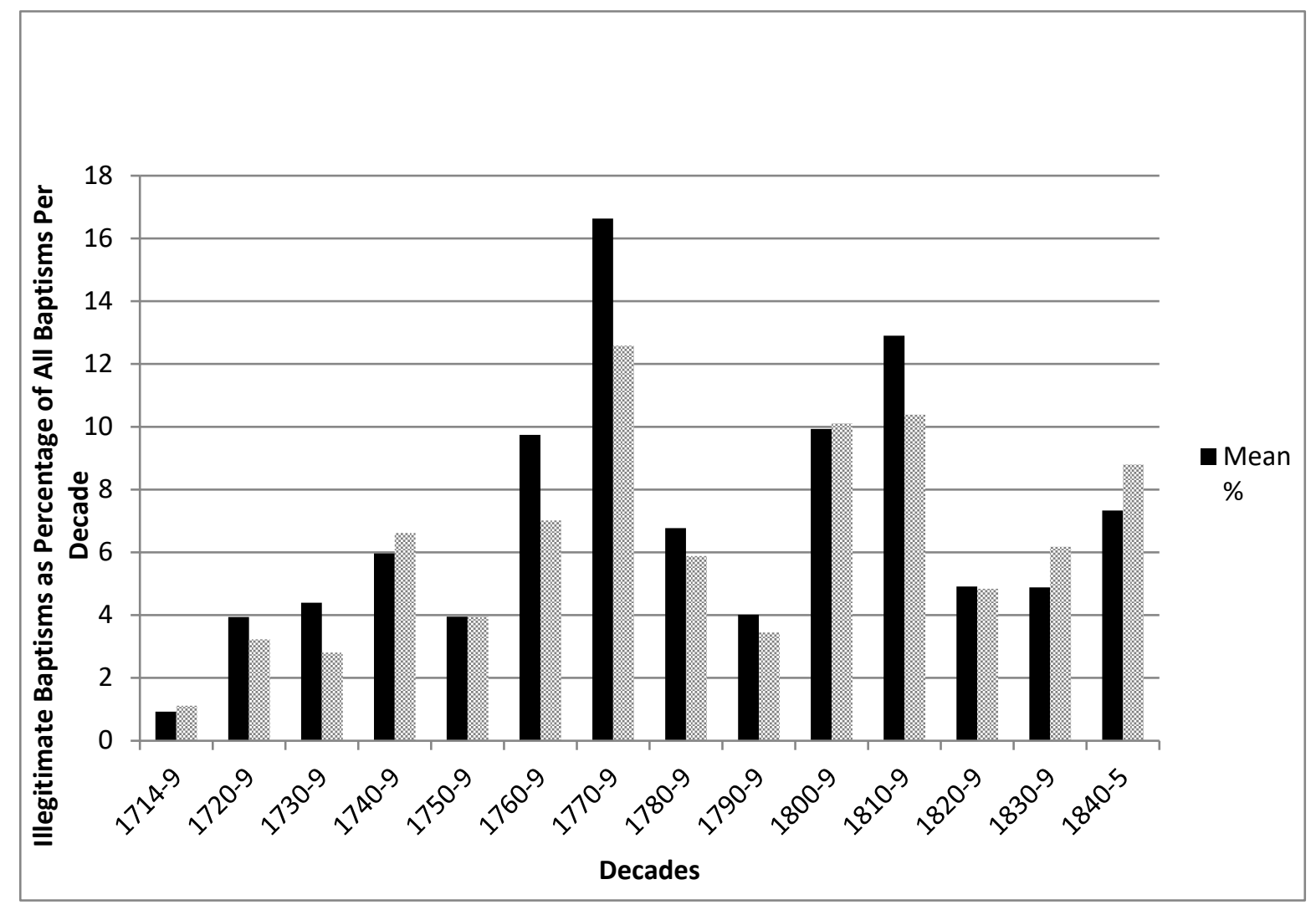

Figure 3. Crude Illegitimacy Ratio, Compared to Illegitimacy Ratio Calculated Excluding Years of Potential Under-Recording, Butleigh, Somerset, 1714-1845.

The overseers were energetic in recovering as much money as possible from fathers named in filiation orders. Between 1762 and 1828, the overseers received money from at least 43 fathers, from whom they recovered a median of 53 percent of the money they laid out in maintenance in this period, slightly above Nutt's median figures for southern England in 1832 (Nutt 2010). Overall, the parish recouped $£ 872$ out of the $£ 1807$ it spent in these years.Generally fathers paid lump sums which averaged approximately $£ 110 \mathrm{~s}$ every 20 weeks, or between $1 \mathrm{~s}$ and $1 \mathrm{~s} 6 \mathrm{~d}$ per week by 1800 , and increasing to $2 \mathrm{~s}$ or $3 \mathrm{~s}$ per week after 1815 . While young single men may have managed to pay these sums, this financial responsibility may have become more burdensome if they married and had further children to support. On average, fathers of one illegitimate child made payments to the overseers for 5-6 years after the baptism, amounting to an average of $£ 16.5$ per child over that period, although the records may under-estimate fathers' total contribution. 


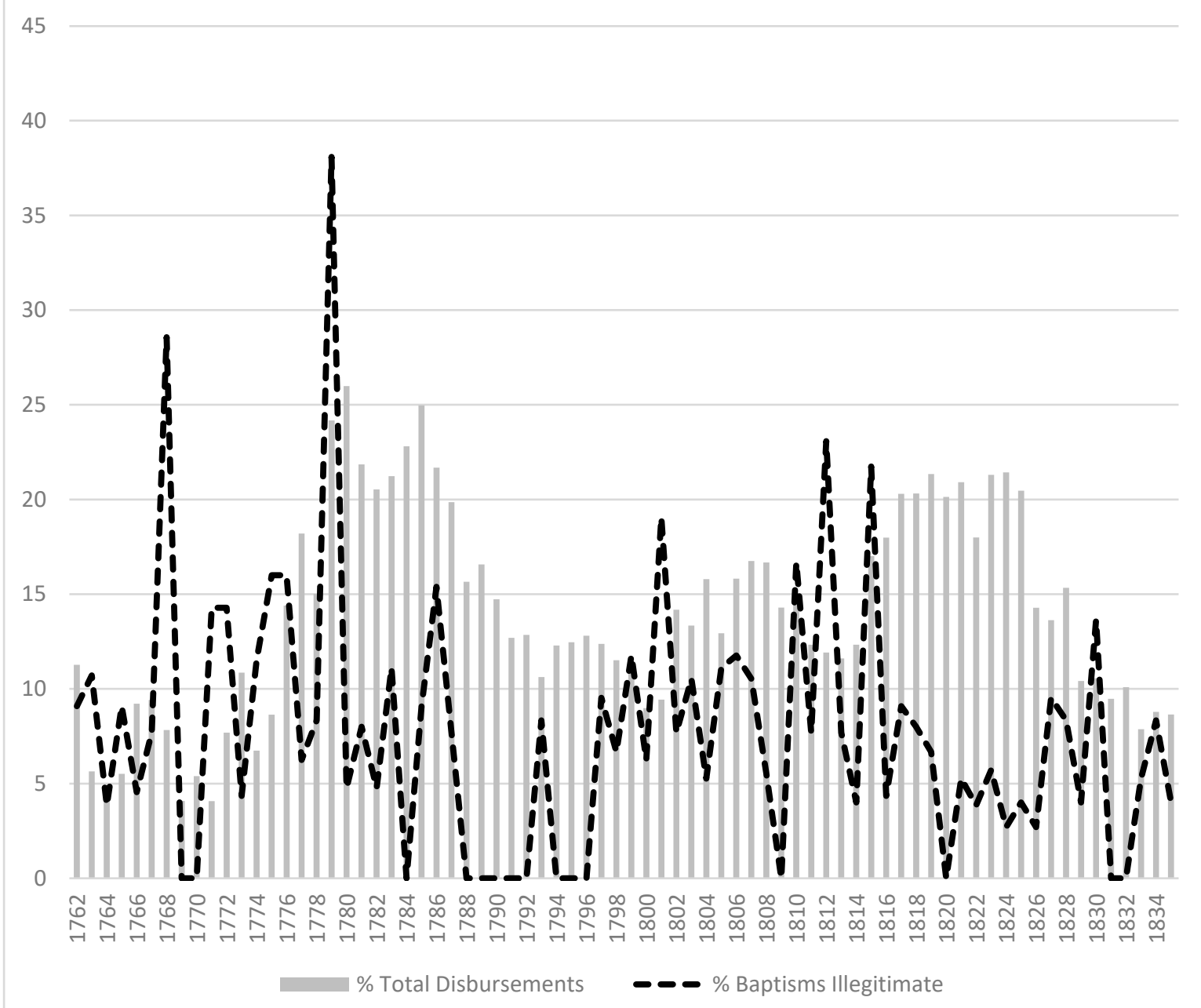

Figure 4. Butleigh, Somerset, 1762-1834: Percentage of Total Value of Annual Poor Relief Disbursements Paid to Illegitimate Children and their Mothers, Compared to Annual Percentage of Baptisms Recorded as Illegitimate.

\section{Pre-Nuptial Pregnancy and Illegitimacy in Butleigh, 1700-1850}

As Peter Laslett and Angela Muir have explained, legal illegitimacy was the result of a complex chain of actions or evasions from the first meeting of the prospective parents to the eventual registration of the baptism (Laslett 1977; Muir 2018). The recording of these events is also fraught with difficulties. After the decline of the Church Courts in the late seventeenth century, sexual activity outside marriage was only really recorded when it resulted in the pregnancy of an unmarried woman, or of a married women no longer co-habiting with her husband. Sexual activity that did not result in pregnancy was not recorded by overseers of the poor or Quarter Sessions. Similarly, because pregnancy outside marriage was the primary administrative concern, this was the most frequent circumstance in which male sexuality was recorded, in order to establish paternity (and financial liability). The only other one was in a minority of criminal cases of male sexual violence or 'deviance'.

The recording of baptisms also presents problems. Demographic studies have demonstrated that infants were usually baptised relatively soon after birth, so that they did not die unbaptised when they were most at risk. However, Berry and Schofield found that the gap between birth and baptism increased between the early seventeenth and later eighteenth centuries, to an average of around 30 days (Berry and Schofield 1971). Parishes may also have conducted baptisms in batches at certain times in the month (particularly following religious holidays, or where the clergyman was a non-resident pluralist), or baptism may have been delayed to allow the mother to attend. So, for example, while 
the illegitimate children of Mary Corpe, Bridget Look and Ann Hodges were all baptised on 5 April 1779, they may not all have been born in the preceding month. In Table 1, the time between the date of marriage and of the baptism of the first child has been calculated plus or minus one month, to account for some of this ambiguity, but perhaps not all. The table is based on 693 marriages and baptisms recorded in the Butleigh.org web-pages between 1700 and 1850, where a precise date is given for both events. These include couples who were not married or resident in the village, but who were connected with it. This can be justified because it sets the behaviour of couples in Butleigh within a broader local context. The sample has been divided into two 75-year periods that happen to fall either side of the apparent increase in the numbers of illegitimate baptisms from the 1770s.

Table 2 shows relatively little change over time. In both time periods, just over one-third of baptisms occurred within 9-10 months of marriage, indicating that the child was probably conceived as a result of sexual activity before marriage. A further 20 percent of baptisms were probably the result of sexual activity after marriage, but not certainly. This figure matches those given in Reay's micro-study of Dunkirk and Hernhill in Kent (Reay 1990). The remaining 40 percent of baptisms occurred outside this time-frame, assuming that there were not long delays between birth and baptism. Obviously, sexual activity outside marriage could have occurred in each of these two latter instances as well, but without resulting in a successful pregnancy.

Table 2. Pre-Nuptial Pregnancy in Butleigh, Somerset, 1700-1850: number of months baptisms occurred after marriage date.

\begin{tabular}{|c|c|c|c|}
\hline 1700-1774 & \multicolumn{2}{|c|}{ Number of } & \\
\hline Months & Baptisms & \multicolumn{2}{|c|}{$\%$ Baptisms } \\
\hline $0-3$ (or 4) & 31 & 12.5 & \multirow{3}{*}{35.9} \\
\hline $4-6$ (or 7) & 23 & 9.3 & \\
\hline 7-9 (or 10) & 35 & 14.1 & \\
\hline 10-12 (or 13) & 62 & 25.0 & 25.0 \\
\hline $13-24$ (or 25) & 62 & 25.0 & \multirow{2}{*}{39.1} \\
\hline $25+$ & 35 & 14.1 & \\
\hline Total & \multicolumn{2}{|l|}{248} & \\
\hline 1775-1850 & \multicolumn{2}{|c|}{ Number of } & \\
\hline Months & Baptisms & \multicolumn{2}{|c|}{$\%$ Baptisms } \\
\hline $0-3$ (or 4) & 47 & 10.6 & \multirow{3}{*}{38.0} \\
\hline $4-6$ (or 7) & 53 & 11.9 & \\
\hline 7-9 (or 10) & 69 & 15.5 & \\
\hline $10-12$ (or 13) & 82 & 18.4 & 18.4 \\
\hline $13-24$ (or 25) & 125 & 28.1 & \multirow{2}{*}{43.6} \\
\hline $25+$ & 69 & 15.5 & \\
\hline Total & 445 & & \\
\hline
\end{tabular}

Despite the error-factors inherent in the recording of baptisms, pre-nuptial pregnancy was recorded about as often in the Butleigh parish registers as it was in a number of other English villages at this time (Oosterveen et al. 1980; Levine and Wrightson 1980; Levine 1977; Ingram 1987). Consequently, its sheer probability must help explain the prevailing numbers of illegitimate baptisms in the village: if two or more of the 4 to 6 brides in the village each year were pregnant, it may not be very surprising that every other year at least one unmarried women also registered a baptism. However, this assumption is based on the idea that the majority of sexual activity outside marriage was courtship-related. The detailed familial evidence in Butleigh suggests that some of it was not. 


\section{Demographic Characteristics of Illegitimacy in Butleigh, 1762-1834}

Mothers and fathers of illegitimate children in Butleigh had a similar age-profile to couples who did go on to marry. Figures 5 and 6 compare the ages at which the 57 identified mothers and 41 fathers of illegitimate children registered their first baptism, compared to the general populations of 542 men and 491 women for whom age-data is available in the Butleigh.org website sample. These figures are biased towards parents whose own baptisms were registered in, or near, Butleigh. As ever, the highly mobile are less likely to offer age-data. Each entry on the Butleigh website was checked to ensure that the birth-date given appeared consistent with the other dates given for each family entry. Any outliers (such significant time discrepancies between birth dates and marriage dates) were discarded. In addition, the much smaller sample size of parents of illegitimate children introduces potential distortions. Despite these caveats, several trends are apparent for mothers and fathers of illegitimate children. Both groups of men and women were increasingly likely to register a first baptism in their early twenties, with a slow decline thereafter, but Figure 5 suggests that mothers of illegitimate children seem to have been marginally younger than most women in the sample. A quarter of the mothers of illegitimate children were under 21 when they registered their first child, compared to 18 percent of all mothers. While this difference is not dramatic, it implies a detectable deviation from the social 'norm' of pregnancy and baptism (Levine 1977; Oosterveen et al. 1980).

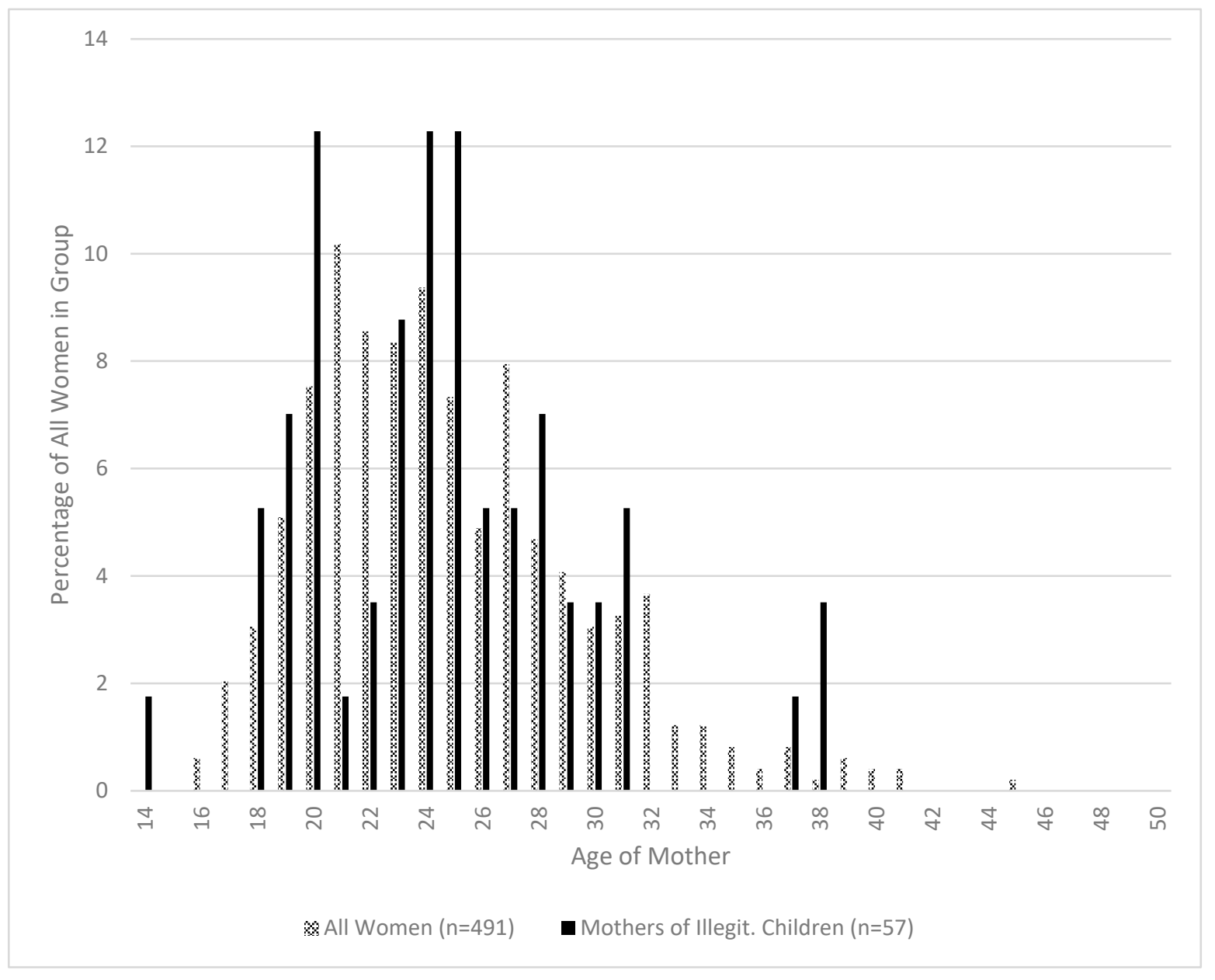

Figure 5. Cont. 
Schematic Family Tree of the Withers-Davis-Isaac-Hockey Callow-Connections:
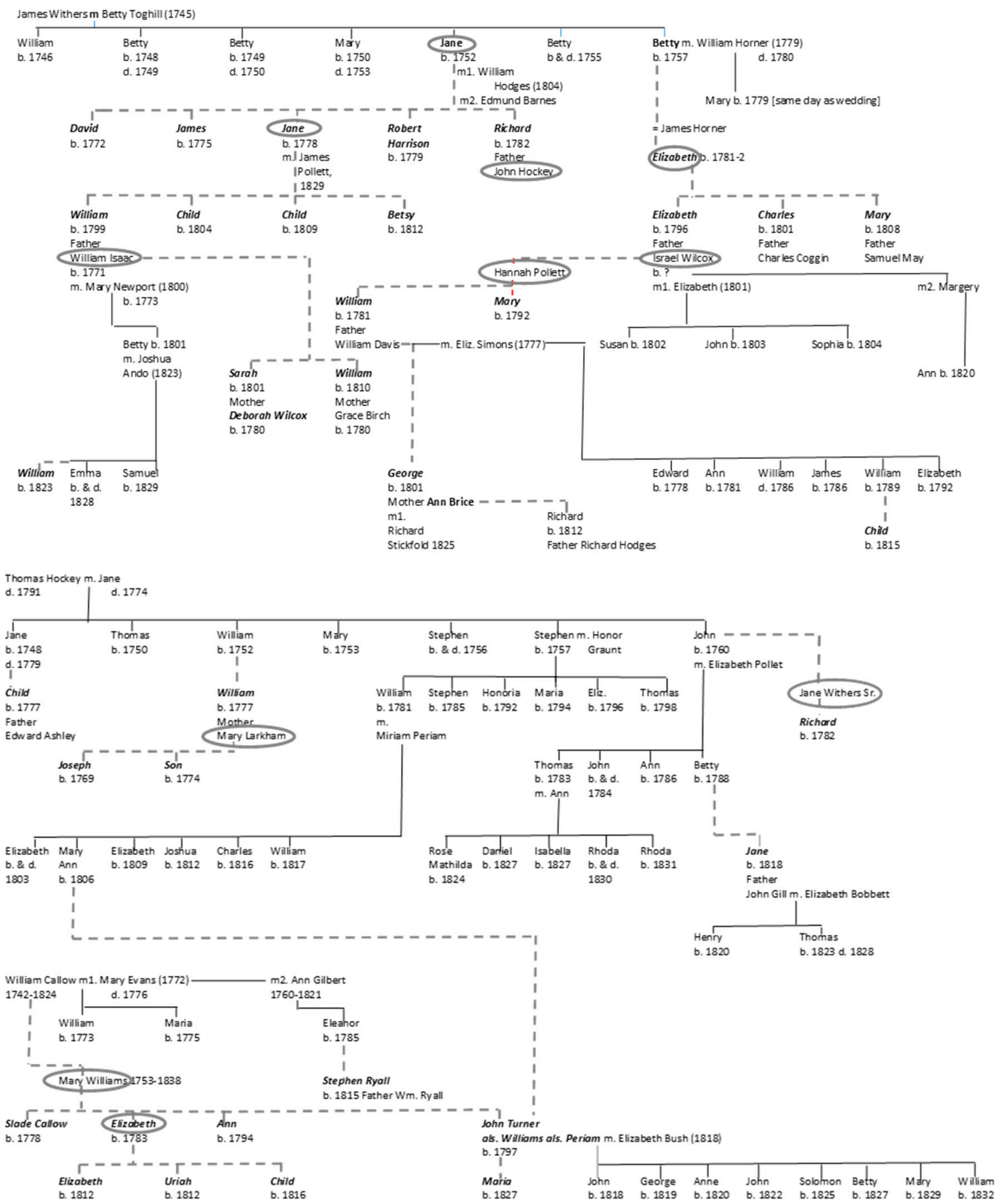

Figure 5. Age at Which Women Registered First Child, All Women vs. Mothers of Illegitimate Children, Butleigh, Somerset, 1762-1834.

The sample of fathers of illegitimate children is even smaller, and might be more subject to random variation. Figure 6 illustrates that fathers of illegitimate children followed the age-range of the general population of men. Some may have been slightly younger than average, but through their twenties the patterns were similar. Thereafter, fathers of illegitimate children continued to register the births of first children well beyond the ages when most men did so. Thirty-two percent of first-time fathers of illegitimate children were aged over 30 years, where only 20 percent of all fathers were first-time parents. The former group conceals a number of men who had already fathered legitimate children. Some of them were widowers when their illegitimate child was baptised, but a small and distinctive 
minority were already married, and later went on to father further legitimate children with their wives. These will be discussed in more detail below.

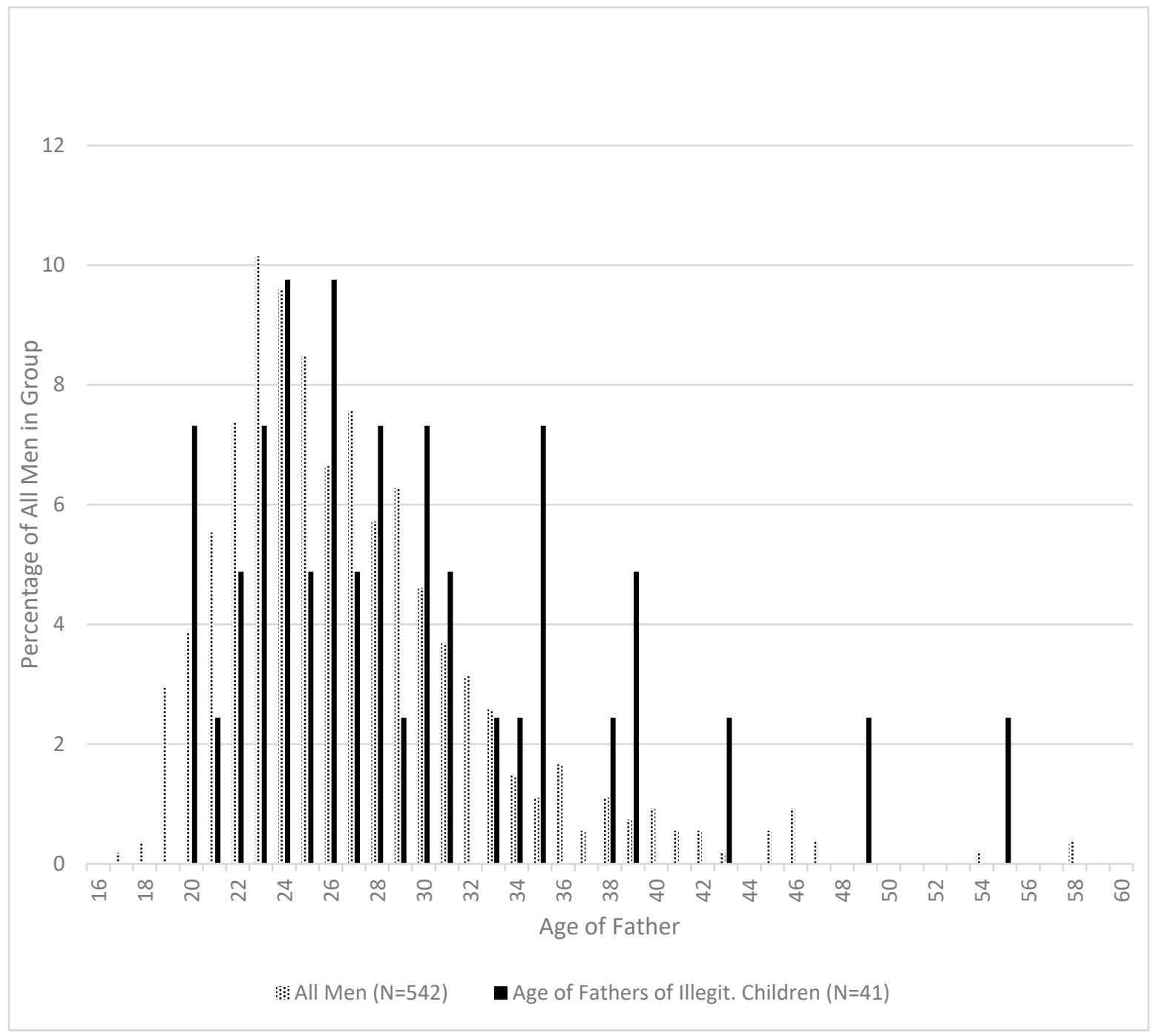

Figure 6. Age At Which Men Registered First Children, All Men vs. Fathers of Illegitimate Children, Butleigh, Somerset, 1762-1834.

The subtle differences between the age-profiles of the mothers and fathers of illegitimate children compared to the parents of legitimate first-borns were not really accompanied by significant variations in the seasonality of conceptions among each group. Table $3 \mathrm{a}, \mathrm{b}$ illustrate the potential month of conception for all first-born children in the Butleigh.org sample and for illegitimate children in Butleigh. Again, the uncertain relationship between birth-dates and baptismal dates makes this calculation imprecise. To allow for some of these variations, a 'maximal' estimate has been used, of 300 days before the recorded baptismal date for each child, consistent with the approach adopted in Table 1. While there appears to be a pattern of conceptions in the first quarter of the calendar year (January to March) for all first-born children, the trends for illegitimate children are less distinctive. These children were slightly more likely than all children to have been conceived in the latter half of the calendar year (July-December), but also, potentially in the second quarter of the year (April-June). There may be a slight bunching effect that coincides with the half-year dates of Ladyday and Michaelmas among both samples, when young, unmarried servants were paid and sometimes discharged from service, but it appears relatively modest. 
Table 3. (a) Butleigh and District All First Children, 1700-1849; (b) Butleigh, Illegitimate Children, 1714-1834.

\begin{tabular}{|c|c|c|c|c|c|}
\hline \multicolumn{6}{|c|}{ (a) } \\
\hline \multicolumn{6}{|c|}{ Possible Conception Months (Baptism Date Minus 300 Days) } \\
\hline 20-Yr Periods & Q1 & Q2 & Q3 & Q4 & Total \\
\hline $1700-1709$ & 33.3 & 0.0 & 66.7 & 0.0 & 3 \\
\hline $1710-1729$ & 26.9 & 9.6 & 19.2 & 23.1 & 52 \\
\hline $1730-1749$ & 35.1 & 6.8 & 14.9 & 24.3 & 74 \\
\hline $1750-1769$ & 22.0 & 7.0 & 27.0 & 30.0 & 100 \\
\hline $1770-1789$ & 20.2 & 14.6 & 28.1 & 20.2 & 89 \\
\hline 1790-1809 & 25.7 & 11.4 & 15.2 & 33.3 & 105 \\
\hline $1810-1829$ & 29.0 & 5.3 & 22.1 & 28.2 & 131 \\
\hline \multirow[t]{2}{*}{ 1830-1849 } & 32.7 & 6.2 & 21.0 & 20.4 & 162 \\
\hline & & & & & 716 \\
\hline \multicolumn{6}{|c|}{ (b) } \\
\hline \multicolumn{6}{|c|}{ Possible Conception Months (Baptism Date Minus 300 Days) } \\
\hline 20-Yr Period & Q1 & Q2 & Q3 & Q4 & Total \\
\hline \multicolumn{6}{|l|}{ 1700-1709 } \\
\hline $1710-1729$ & 0.0 & 50.0 & 33.3 & 16.7 & 6 \\
\hline 1730-1749 & 28.6 & 21.4 & 42.9 & 7.1 & 14 \\
\hline 1750-1769 & 28.0 & 24.0 & 20.0 & 28.0 & 25 \\
\hline 1770-1789 & 27.5 & 35.0 & 25.0 & 12.5 & 40 \\
\hline 1790-1809 & 22.7 & 22.7 & 22.7 & 31.8 & 22 \\
\hline 1810-1829 & 27.3 & 21.2 & 15.2 & 36.4 & 33 \\
\hline \multirow[t]{2}{*}{ 1830-1834 } & 25.0 & 12.5 & 31.3 & 31.3 & 16 \\
\hline & & & & & 156 \\
\hline
\end{tabular}

\section{Illegitimacy and Family Situation}

So, in Butleigh there was little difference between the parents of illegitimate children and legitimate first-born children, in terms of the age at which this sexual activity occurred and its seasonality, because for over one-third of all prospective first-time parents this activity took place outside marriage. Although their paths diverged once the pregnancy was acknowledged, to some extent conceptions occurred among a group of young people who appear relatively homogeneous, as far we can determine from the surviving historical record.

However, significant detail differences are revealed by a closer examination of the circumstances of the (large) subset who went on to depend on poor relief. Table 4 illustrates some of the characteristics of these 77 women and 58 men in Butleigh between 1762 and 1834. This sample contains some observation biases. Overseers' accounts tell us most about mothers who remained unmarried and dependent on relief during their child's infancy and youth, and less about those who married, moved on, or died outside the village. Similarly, they reveal much more about the family circumstances of co-operative fathers located within the village, than those who were itinerant, evasive or who lived elsewhere. Even so, the table highlights some distinctive traits. 
Table 4. Characteristics of Parents of Illegitimate Children Receiving Poor Relief, Butleigh 1762-1834 *.

\begin{tabular}{lcc}
\hline & \multicolumn{2}{c}{ Percentage of } \\
\cline { 2 - 3 } & WOMEN & MEN \\
\hline Subject is also illegitimate & 13.0 & 8.6 \\
Parent has other illegitimate children & 9.1 & 10.3 \\
Sibling has illegitimate child & 14.3 & 17.2 \\
Subject marries Mother/Father of illegitimate child & 10.4 & 12.1 \\
Subject marries somebody other than illegitimate child's Mother/Father & 20.8 & 39.7 \\
Subject is already married to someone else when child born & 1.3 & 15.5 \\
Widow/Widower when illegitimate child born & 2.6 & 5.2 \\
Never marries (in Butleigh) & 64.9 & 32.8 \\
Has other illegitimate children with same Mother/Father & 2.6 & 0.0 \\
Has other illegitimate children with another Mother/Father & 33.8 & 5.2 \\
Has other illegitimate child with parent of illegitimate child & 5.2 & 3.4 \\
\hline NUMBER & 77 & 58 \\
\hline Median Age of First Marriage & 25 & 27 \\
Median Age when illegitimate child born & 24 & 27 \\
\hline
\end{tabular}

Note-Marriage characteristics relate only to marriages recorded within Butleigh and surrounding parishes, identified in the Buleigh.org 'Butleigh People' index and via FindMyPast marriage indices. Other marriage may have occurred which are not reflected in this table.

Firstly, it illustrates that women's marriage prospects were reduced significantly by having given birth to an illegitimate child. Only 10 percent of the group married the child's father. A further 20 percent married another man, but almost two-thirds of unmarried mothers in the village never married, which was within the range identified by Adair, but a lower proportion than in Reay's study later in the nineteenth century (Adair 1996; Reay 1990). In fact, these women were more likely to have another illegitimate child than they were to marry anyone in Butleigh. This implies that illegitimacy imposed a real impediment to marriage for women who remained in the village. Men in the group showed a greater propensity to marry, and were much less likely to father another illegitimate child, but they were much more likely than women to marry somebody other than the parent of their child. The other notable characteristic among men is that a significant minority of fathers (16 percent) were already married to another woman when they fathered an illegitimate child. Their presence increases the mean age at which men fathered an illegitimate child so that it is above the mean age of first marriage for the group.

The other familial characteristic was that between 10 and 20 percent of the sample were either illegitimate themselves, or connected within their immediate parental family or sibling group to someone who was also the parent of an illegitimate child, although this was a lower proportion than in Dunkirk or Hernhill, Kent (Adair 1996; Reay 1990). In one respect, these connections are not surprising given the prevailing levels of pre-nuptial pregnancy in Butleigh, however, as we will see in some instances illegitimate children were the sole off-spring of women who were themselves illegitimate. In other cases, two female siblings had illegitimate children and eventually resided together most of their lives in the same house, maintained partly by the parish. Detailed reconstruction of family networks suggests that although illegitimacy was relatively common in Butleigh, it may have acted as a social marker within the village, creating social categories (and value-judgements) from which it was difficult to escape.

\section{Family Experiences of Illegitimacy in Butleigh}

\subsection{Surnames}

Although women who had illegitimate children in Butleigh often did not marry, this was not an invariable rule. In 1783, Ann Wheeler had a son, Joseph, with Joseph Godfrey, who was later sanctioned repeatedly by the overseers for payment of maintenance, as shown above. Three years later, 
Ann had a second child, David, with Richard Farnham of nearby Compton Dundon. In 1790, Ann married Richard, and her household consisted of her two illegitimate sons, and (eventually) three other children. In one sense, Ann's history confirms that it was possible for a single women, who already had one living illegitimate child eventually to marry and establish a stable household. However, her son David's subsequent behaviour is interesting in this respect. He baptised his four children in his father's parish, where they carried the Farnham surname. So, his eldest son was christened John Wheeler Farnham in 1816. However, the family lived in Butleigh and in sources there they were referred to consistently by the surname Wheeler. The use of the paternal surname in the paternal parish may have been an attempt to reach for a legal status denied in law, but David's different experience in Butleigh may indicate that it was difficult to escape local knowledge.

The same pattern occurred in the case of Mary Williams' son, John. Her experience will be discussed more fully below, but John was the youngest of her four illegitimate children. The identity of his father is unknown, but his son was referred to in the overseers' accounts consistently as John Turner. However, his first four children were baptised in Butleigh with the surname 'Periam'. The next two were baptised using his mother's surname, while the final two were baptised 'Periam' again. In the meantime John had also fathered an illegitimate daughter, Maria, with Eliza Hockey in 1827. This nominal ambiguity may be simple administrative caprice or arbitrary selection in the face of real-world complexity, but it may also suggest John's efforts either to claim or evade a parental identity. Similarly, when another John Periam married in February 1842, he gave his father's name as 'William Perriam dec'd'. In fact, his was father was John Everdell, who had paid maintenance to his mother Anne Periam between 1814 and 1817, before she married William Wheeler. Wheeler had died in 1837, so it is unlikely John Periam was confused about step-father's identity, but may have attempted to obscure his paternity.

More often, a child would be baptised with the mother's surname, but sometimes with the father's incorporated into one of the forenames, as an attribution of paternity. The most extreme example of this was in the naming of the children of Edward Blenman Jr. Edward was described as a 'yeoman', and served as parish overseer in 1755, mortgaged 22.5 acres of land in 1770 (SALS DD/S/BT/8/3/15-33 1 1770), and paid rates until his death in 1772. Although there is no record of his marriage in Butleigh, his wife Elizabeth was buried in 1769. However, during the 1760s Blenman may have fathered as many as seven illegitimate children, with at least three different women. In 1763, Jane Ayres baptised a daughter Jane Blenman. She baptised two more children, Edward Blenman and Elizabeth Blenman, the latter born in 1771, the year after Jane married James Andrews. Jane went on to have seven children with James Andrews, but they lived in a property formerly held by Edward Blenman, possibly as part of his provision for them. However, when Jane Ayres' son Edward Blenman was buried in 1785, he was named 'Edward Eyres'. The year after Edward Blenman's death, Elizabeth Curtis buried a son 'Edward Blenman', having previously given birth to a daughter 'Elizabeth Blenman' in 1769. In 1765, Blenman was given as the father of another son, to an unnamed woman. Finally, Jane Hodges gave birth to a daughter Ann in 1767, whose father was given as '_ Blenman'. While it is possible that Edward Blenman Jr was not the father of all these children, the concentration of naming within a narrow time-frame implies a desire on the part of the parents or the parish to highlight the nominal (and financial) linkage. Blenman provided privately for these children without recourse to the overseers, so their mothers may have given particular emphasis to recording paternity in this way.

\subsection{Illegitimacy in Its Social Context}

Blenman's example highlights the importance of locating illegitimacy within its social context. As Reay's criticisms of the 'bastardy-prone sub-society' emphasise, though, there are grave dangers of jumping to conclusions, and imposing gendered preconceptions in circumstances where very little evidence exists. As has been shown, the majority of illegitimate children in Butleigh were born to young unmarried women and men, within a wider cohort of sexually active 'courting' couples in their early to mid-twenties, most of whom went on to marry. In the sample group of 77 mothers who 
received poor relief, 48 or 62 percent bore only one illegitimate child, and only 16 (or 20 percent) had two children. The remaining thirteen women had three or more illegitimate children. While equivalent figures for men carry the risk of under-recording, 89 percent of men in the sample were identified as the father of only one illegitimate child. So, parents of multiple illegitimate children were unusual in Butleigh, but is there any evidence that they were corralled together by popular opinion, in the way that the term 'sub-society' implies?

Edward Blenman illustrates that a fairly prosperous middle-aged man could flout social and moral conventions repeatedly, possibly because his behaviour was never made public through the overseers' accounts. His case also reveals significant disparities in age and authority as well. When Jane Ayres conceived her first child, she would have been 16 or 17 years old, while Blenman was 44 . Elizabeth Curtis' age is uncertain, while Jane Hodges was 28 years old when her daughter Ann was born. Similarly, in 1815 Eleanor Callow gave birth to William Ryall's son, Stephen Ryall. Although William Ryall's age is unclear, he was described as a 'bailiff and agent' on the Grenville estate, and had been a co-signatory of several deeds with Eleanor's father William, as early as 1801, when Eleanor would have been only 15 years old. The overseers' accounts also record more obvious instances of socio-economic inequalities. In 1814, Hester Evans gave birth to a daughter, Betsy. The father, James Death paid the overseers a lump sum of $£ 25$ to be freed from any further financial obligation for his daughter, but only after he had been brought to the attention of the local JPs. However, there is no evidence that William Ryall was summoned, nor was John Lovell, father of Jane Talbot's daughter, Mary Ann, in 1823, and referred to consistently thereafter by the overseers with the pre-fix ' $\mathrm{Mr}^{\prime}$. By contrast 78 percent of putative fathers in the parish relief sample were cited, or even imprisoned, by the JPs. Of the 52 fathers from whom the overseers secured maintenance in the period, 15 (or 28 percent) appear to have paid rates at some point in their lives on properties in Butleigh, while 23 (or 40 percent) received poor relief (often only in sickness or old age). Although some of the other fathers may have paid rates in neighbouring parishes, this suggests that only a minority of fathers were, or would become, more prosperous than the majority fathers in the village, who never paid rates on their houses, but who never received poor relief, either. While there is insufficient evidence in Butleigh to reconstruct the occupations of fathers of illegitimate children, as in Reay, (Reay 1990), the relative absence of relief recipients among these fathers implies both that some did not live in Butleigh, but also that others may not have been deterred from marriage by being unusually poor.

Oosterveen and Smith, Adair, Levine and King have highlighted the disproportionate impact on illegitimacy levels of the relatively small number of mothers, 'repeaters' in Laslett's gendered terminology, who baptised several illegitimate children, and they have been the focus of research on the 'bastardy-prone sub-society' (Oosterveen et al. 1980; Levine 1977; King 2005). Somewhat less has been said about the participation of men in illicit sexual activity (Adair 1996; Reay 1990; Williams 2018; Nutt 2010). As has been noted, in Butleigh nine out of 58 fathers in the parish relief sample (excluding Edward Blenman Jr) were already married when they fathered illegitimate children, compared to two of the mothers (who had been deserted by their husbands before their children illegitimate were born). When their first illegitimate child was born, the average age of these fathers was 33.5 years, with a range between 26 and 49 years. Consequently, most such men had been married for at least a decade before an extra-marital relationship resulted in pregnancy. In some cases, these men had also fathered children before marriage. The sample family trees illustrate some of the potential complexity of these connections, and how the isolation of a 'sub-society' can be misleading. The trees illustrate the relationships between five diverse family groupings, those associated with the children of James Withers, Thomas Hockey, William Isaac and William Callow. Between them, these families accounted for 26 of the 81 illegitimate children (34 percent) baptised in Butleigh between 1769 and 1815. They have been chosen both because of the density of their inter-connections and because they illustrate a very broad spectrum of behaviour: legitimate baptisms, bridal pregnancy, individual illegitimate children followed by the marriage of the parents, illegitimate births after which the father married another woman, single illegitimate baptisms after which the mother remained unmarried, illegitimacy 
involving a widowed mother, multiple illegitimate baptisms to an unmarried mother, illegitimate children fathered by a married man, and two successive generations of illegitimacy.

Certain trends are very apparent, notably the presence of women who had multiple illegitimate children. For example, Jane Withers Sr. had five illegitimate children with different fathers, including John, son of Thomas Hockey. Her daughter Jane had four illegitimate children. Yet, both women married, but only after they had passed child-bearing age and their children had grown up. Jane Sr.'s niece Elizabeth also had three illegitimate children by three different fathers, but never married. Thomas Hockey's son William fathered the third of Mary Larkham's illegitimate children in 1777. Occasionally, the overseers' records provide a few hints of possible circumstances. In 1778 Mary Williams was being paid by the overseers for looking after Hester Callow's three illegitimate children. It is not clear what relation Hester Callow was to William Callow, but it was during this period that William, whose first wife had died two years previously, fathered Mary's first child, Slade Callow Williams. Mary had three more illegitimate children, her daughter Elizabeth also had three illegitimate children, while her son John fathered an illegitimate child nine years after he was married, with Mary Ann Hockey, great granddaughter of Thomas Hockey. As was shown above, this John Turner als. Williams als. Periam alternated the surnames by which he registered his legitimate children.

This behaviour can be interpreted in several different ways. Since the parish paid most of the direct costs incurred by these children, it could be argued that for these women the financial disincentives to illegitimacy were limited. Was this therefore sexual non-conformity at the parish's expense? Such an interpretation ignores the obvious restrictions that children imposed on the earning capacity of these women, in families which lacked an adult male wage. It also implies that the parish authorities were tolerant of such behaviour, when all the available evidence shows that they were strenuous in establishing paternity and enforcing maintenance payments, and consistent in expressing pejorative descriptions of illegitimacy. For example, although the parish overseers made 154 payments totalling $£ 36$ over the 13 years that they paid for Mary Larkham and William Hockey's son William, the payments averaged only $1 \mathrm{~s}$ per week before William's seventh birthday and $1 \mathrm{~s} 6 \mathrm{~d}$ per week thereafter. William was referred to routinely as 'William Hockey's bastard by Mary Larkham', 'William Hockey's bastard' or 'Mary Larkham's bastard'. This implies that illegitimacy was stigmatised, and attached publicly as a label, to parents and children alike. Conversely, though, all of these mothers remained long-term residents in the village, as were many of their children. While we cannot judge the strength or efficacy of their connections to the Withers, Hockey or Callow families, there is also no evidence that they were a socially segregated group.

There is also the question of hindsight. Jane Withers mother and daughter, Mary Larkham, Mary and Elizabeth Williams end up in the records as the unmarried mothers of multiple children. It is dangerous to infer from this that they never intended to marry. They may have engaged in sexual activity during courtship in order to cement an intended marriage, as Jane Withers Sr.'s sister Betty did in 1779, or William Isaac's daughter Betty managed in 1823 after the birth of an illegitimate son fathered by Joshua Ando. Their life-chances may also have been affected adversely by engaging in sexual activity that resulted in pregnancy a few years earlier than most of their peers. Jane Withers Sr. was 20 when her first child was baptised. Her daughter was 21. Her niece Elizabeth was only 15 or 16 when her first child was baptised, although Mary and Elizabeth Williams were 25 and 29 years old respectively. This issue of life-chances brings up the question of the behaviour of some of the fathers of these children.

In particular, it is worth focusing attention on William Isaac, William Davis, Israel Wilcox and John Turner als. Williams als. Periam. William Isaac fathered Jane Withers Jr.'s first son William in 1799. He married Mary Newport in 1800 and their daughter Betty was baptised in 1801. However, the same year, Isaac was also named as the father of Deborah Wilcox's daughter Sarah, and in 1810 fathered Grace Birch's son William. Significantly, perhaps, while Isaac was in his late 20s, both Jane Withers Jr. and Deborah Wilcox were illegitimate themselves, and quite young. Jane was 21 and Deborah only 19 when their children were baptised, while William's wife, Mary Newport, was 27 years old. William 
Davis married Elizabeth Simons in 1777, at the age of 23, and had six children with her between 1778 and 1792. However, in 1781 he also fathered Hannah Pollett's first illegitimate child, and in 1801, aged 47 he fathered Ann Brice's first child, when Ann was 27 years old. Israel Wilcox married his wife Elizabeth in 1801, but he had previously fathered Hannah Pollett's second child, Mary, in 1792 and Elizabeth Withers' first illegitimate child in 1796, when she was only 15 or 16 years old. John Turner als. Williams als. Periam was 30 years old and the father of five children with his wife Elizabeth, when he fathered Mary Ann Hockey's daughter Maria in 1827, the same year his sixth child was born. Mary Ann was 20 or 21 years old. Some of these age differences intersected with modest differences in status, between male householders and young, poorer, unmarried women.

These instances raise a number of questions. While William Davis' legitimate family had been completed some years before the baptism of his second illegitimate child, all of these fathers were resident, without any sign that they had deserted their wives, or that they co-habited with the mothers of their illegitimate children. Israel Wilcox and John Turner als. William als. Periam had additional children with their wives after the baptism of their illegitimate children. Obviously, therefore, on their part this sexual activity was not in anticipation of marriage or courtship in a conventional sense. As we have indicated above, the significant age differences between some of these men and the women who bore their children, and the illegitimate birth of some of those women, implies a difference in power-relationships between older, more established (if still labouring) men, and young unmarried, and potentially stigmatised women who were either hired or day-servants in and around the village and its farms. It indicates that there were clearly some men for whom marriage did not mark the end of 'pre-marital' sexual behaviour, and (presumably) some young women whose sexual activity was not necessarily oriented primarily towards marital courtship. Presumably, these instances of illegitimacy also offer a brief glimpse into the hidden world of extra-marital sexual activity between married men and women.

In these circumstances, while the behaviour of a small group of women and men in Butleigh generated a set of a-typical records in parish registers and the overseers' accounts, they may be less of a 'sub-society' than other parish studies have suggested. The fact that most unmarried fathers of illegitimate children had to be summonsed or even gaoled before they provided maintenance implies that marriage may never have been in prospect for them either, or that these relationships had broken down by the time the child was baptised. However, the evidence of these complex family trees also indicates that illegitimacy recurred within certain familial groupings, such as the Withers or the Williams, and the records of Butleigh indicate that illegitimacy was stigmatised. Were the Withers and Williams children regarded as undesirable marriage partners because of their parentage? Did the socio-economic disadvantages conferred by this parentage make them less desirable instead? Sadly, the available evidence does not provide any reliable answers. However, it is evident that girls from these families were financially dependent on the parish, and often lodged as inmates or servants with other recipient families. In such circumstances, one wonders whether the unequal power relationships with older men slipped into outright exploitation.

\section{Conclusions}

In these respects, the situation in Butleigh bears a strong resemblance to Reay's Kentish communities later in the nineteenth century. Illegitimacy in this Somerset village was a compound phenomenon, in which the numerical majority of parents were young single women and men, but a significant proportion of the children baptised outside marriage were born to mothers who had more than one such child, and sometimes to fathers who were already married. Similarly, while most parents of illegitimate children were not illegitimate themselves, a minority were, and were sometimes enmeshed in families where other siblings were illegitimate, or bore illegitimate children. Butleigh lacks 'bastardy examinations' or the Petty Sessions evidence that Reay uses to detail the 'rough' plebeian sexual culture of Dunkirk and Hernhill. Some of the scenarios identified in Butleigh point to similar male exploitation of unequal gender and power relations, as well as a sexual culture of 
illicit liaisons not oriented towards 'courtship'. Our difficulty is that while the administrative category of 'bastardy' obviously was not the only variety of pre- and extra-marital sexuality, it dominates the documentary record.

Should it therefore form the basis of the definition of overt, self-conscious social and sexual non-conformity? Certainly, the evidence from Butleigh suggests that illegitimacy could carry life-long consequences for the parents of illegitimate children, particularly the mothers, and for the children themselves. Bearing an illegitimate child drastically reduced the likelihood of marriage for women, and was also (perhaps counter-intuitively) a disincentive for the father to propose marriage. Some children (or some parish administrators) seem to have grappled with the complex legacy and the stigma of illegitimacy by juggling surnames, and familial identities. This implies that parents and children were 'marked out' by illegitimacy, but were they also separated off into a 'sub-society'? The situation in Butleigh indicates that it may be better to analyse multiple births outside marriage in terms of the idea of social 'closures' or constrictions within a single societal value-system, rather than as evidence for the existence of a consciously 'deviant' alternative. Setting mothers of multiple illegitimate children in the context of their wider genealogy certainly shows the presence of some affinities with other such mothers. However, it also reveals that they were sisters, aunts, nieces, and cousins of many others whose family structures were more conventional. Similarly, the fact that these women lived most of their lives in the village, as servants, employees, neighbours, care-givers, and (presumably) friends of a wider community, suggests that they were integrated into this community and its values-even if these included acceptance of some of Reay's depressing male culture of exploitation and importuning. This is a point worthy of further research. The records of poor relief certainly offer the prospect of additional insights into whether or not mothers of multiple children were paid less per child, more likely to be removed from the parish, or to be required to care for other paupers, than other female recipients. They may well have been stigmatised, discriminated against and disadvantaged within this system, but any judgement that they 'rejected' it rests on a retrospective, and unsupported, reading of intent into the events within their life histories. Instead, perhaps we should adopt the genealogical 'gaze', and regard illegitimacy as a point of familial and social connection, albeit legally unequal and often burdened by shame, rather than as a normative and societal dividing line.

Funding: This research received no external funding.

Acknowledgments: The author is extremely grateful to R. C. Senior for permission to use these materials included on http:/Butleigh.org/ in the current study.

Conflicts of Interest: The author declares no conflict of interest.

\section{References}

\section{Primary Sources}

Somerset ALS, Butleigh Court Papers, DD/S/BT/8/3/15-33 1. 1770. Mortgage of Brownswell, Shelfhedge, Dosthill, Longhill and land in Butleigh West Field. Unpublished work, 1770.

Somerset Archives \& Local Studies DD/S/BT/3/9. 1795. Map of Butleigh allotment on King's Sedgemoor, c. 1795. Somerset ALS DD/S/BT/3/12/12. 1828. Butleigh Court Papers, Tithe Award Survey.

Somerset ALS D/P Butl/13/1/3. 1826-7. Survey and Valuation of Poor Rate Including Tithe Valuations.

UK Parliamentary Papers. 1803-4. 175. XIII. 1. Abstract of the Answers and Returns Made ... 466-7.

https://parlipapers.proquest.com/parlipapers/docview/t70.d75.1803-000625?accountid=10792 (UK P. P. 1830-1) UK

Parliamentary Papers. 1830-1. 83. XI. 227. Account of Money Expended ... 184.

https://parlipapers.proquest.com/parlipapers/docview/t70.d75.1830-012762?accountid=10792

UK Parliamentary Papers. 82. XIX.1. Abstract of Returns ... 416-7. https://parlipapers.proquest.com/parlipapers/ docview/t70.d75.1818-005763?accountid=10792

UK Parliamentary Papers. 556. V. 517. Select Committee on Poor Rate Returns: Report, Appendix. 158.

https://parlipapers.proquest.com/parlipapers/docview/t70.d75.1822-007681?accountid=10792 
UK Parliamentary Papers. 334. IV. 39. Select Committee on Poor Rate Returns: Report, Appendix. 195. https://parlipapers.proquest.com/parlipapers/docview/t70.d75.1825-009397?accountid=10792

UK Parliamentary Papers. 444. XLVII. 185. Account of Money Expended ... 178.

https://parlipapers.proquest.com/parlipapers/docview/t70.d75.1835-015892?accountid=10792

\section{Secondary Source}

Adair, Richard. 1996. Courtship, Illegitimacy and Marriage in Early Modern England. Manchester: Manchester University Press.

Bailey, Joanne. 2006. 'I Dye [sic] By Inches': Locating wife beating in the concept of a privatisation of marriage and violence in seventeenth-century England. Social History 31: 273-94. [CrossRef]

Bailey, Joanne. 2014. 'All he wanted was to kill her that he might marry the Girl': Broken marriages and cohabitation in the long eighteenth century. In Cohabitation and Non-Marital Births in England and Wales, 1600-2012. Edited by Rebecca Probert. London: Palgrave Macmillan, pp. 51-64.

Barclay, Katie. 2019. Love, Care and the Illegitimate Child in Eighteenth-Century Scotland. Transactions of the Royal Historical Society 29: 105-26. [CrossRef]

Berry, Boyd M., and Roger S. Schofield. 1971. Age at Baptism in Pre-Industrial England. Population Studies 25: 453-63. [CrossRef] [PubMed]

Chaytor, Miranda. 1995. Husband(ry): Narratives of Rape in the Seventeenth Century. Gender and History 7: 378-407. [CrossRef]

Clark, Gregory. 2007. The Long March of History: Farm Wages, Population, and Economic Growth, England 1209-1869. Economic History Review 60: 97-135. [CrossRef]

Evans, Tanya. 2005. 'Unfortunate Objects': Lone Mothers in Eighteenth-Century London. Berlin/Heidelberg: Springer.

French, Henry Richards. 2013. Living in Poverty in Eighteenth-Century Terling. In Remaking English Society. Social Relations and Social Change in Early Modern England. Edited by Steve Hindle, Alexandra Shepard and John Walter. Suffolk: Boydell \& Brewer Ltd., pp. 281-316.

Griffin, Emma. 2013. Sex, illegitimacy and social change in industrializing Britain. Social History 38: $139-61$. [CrossRef]

Ingram, Martin. 1987. Church Courts, Sex and Marriage in England, 1540-1640. Cambridge: Cambridge University Press.

Kelly, Jason. 2006. Riots, revelries, and rumor: Libertinism and masculine association in Enlightenment London. Journal of British Studies XLV: 796-818.

King, Steven. 2005. The Bastardy Prone Sub-Society Again: Bastards and Their Fathers and Mothers in Lancashire, Wiltshire, and Somerset, 1800-1840. In Illegitimacy in Britain 1700-1920. Edited by Alysa Levene, Thomas Nutt and Samantha Williams. London: Palgrave Macmillan, pp. 66-85.

Laslett, Peter. 1977. Family Life and Illicit Love in Earlier Generations: Essays in Historical Sociology. Cambridge: Cambridge University Press.

Laslett, Peter. 1980. The bastardy prone sub-society. In Bastardy and Its Comparative History. Studies in the History of Illegitimacy and Marital Nonconformity in Britain, France, Germany, Sweden, North America, Jamaica and Japan. Edited by P. Laslett, K. Oosterveen and R. Wall. Cambridge: Harvard University Press, pp. 217-39.

Levine, David. 1977. Family Formation in an Age of Nascent Capitalism. Amsterdam: Elsevier.

Levine, David, and Keith Wrightson. 1980. The social context of illegitimacy in early modern England. In Bastardy and Its Comparative History. Studies in the History of Illegitimacy and Marital Nonconformity in Britain, France, Germany, Sweden, North America, Jamaica and Japan. Edited by P. Laslett, K. Oosterveen and R. Wall. Cambridge: Harvard University Press, pp. 158-75.

McEwan, Joanne. 2011. Attitudes towards Male Authority and Domestic Violence in 18th century London courts. In Governing Masculinities in the Early Modern Period: Regulating Selves and Others. Edited by Susan Broomhall and Gent Jacqueline Van. Farnham: Ashgate Publishing, Ltd., pp. 247-63.

McNabb, Jennifer. 2006. Ceremony versus consent: Courtship, illegitimacy and reputation in northwest England, 1560-1610. Sixteenth-Century Journal XXXVII: 59-81.

Muir, Angela. 2018. Courtship, sex and poverty: Illegitimacy in eighteenth-century Wales. Social History 43: 56-80. [CrossRef] [PubMed] 
Nutt, Thomas. 2005. The paradox and problems of illegitimate paternity in old poor law Essex. In Illegitimacy in Britain, 1700-1920. Edited by Alysa Levene, Thomas Nutt and Samantha Williams. London: Palgrave Macmillan, pp. 102-21.

Nutt, Thomas. 2010. Illegitimacy, paternal financial responsibility, and the 1834 Poor Law Commission Report: The myth of the old poor law and the making of the new. Economic History Review 63: 335-61. [CrossRef]

Oosterveen, Karla, Richard M. Smith, and S. Stewart. 1980. Family reconstitution and the study of bastardy: Evidence from certain English parishes. In Bastardy and Its Comparative History. Studies in the History of Illegitimacy and Marital Nonconformity in Britain, France, Germany, Sweden, North America, Jamaica and Japan. Edited by P. Laslett, K. Oosterveen and R. Wall. Harvard: Harvard University Press, pp. 86-140.

Probert, Rebecca, ed. 2014. Cohabitation and Non-Marital Births in England and Wales, 1600-2012. Berlin/Heidelberg: Springer.

Quaife, Gerald R. 1979. Wanton Wenches and Wayward Wives: Peasants and Illicit Sex in Early Seventeenth-Century England. Abingdon-on-Thames: Routledge.

Reay, Barry. 1990. Sexuality in Nineteenth-Century England: The social context of illegitimacy in rural Kent. Rural History 1: 219-47. [CrossRef]

Shepard, Alexandra. 2003. Meanings of Manhood in Early Modern England. Oxford: Oxford University Press.

Shorter, Edward. 1971. Illegitimacy, sexual revolution and social change in modern Europe. Journal of Interdisciplinary History II: 237-72. [CrossRef]

Siraut, Mary C., T. Thacker Alan, and Elizabeth Williamson. 2006. Parishes: Butleigh. In A History of the County of Somerset: Volume 9, Glastonbury and Street. Edited by R. W. Dunning. London: Constable, pp. 82-103.

Statt, Daniel. 1995. The case of the Mohocks: Rake violence in Augustan London. Social History 20: 179-99. [CrossRef]

Sutton, G. B. 1979. C. and J. Clark, 1833-1903: A History of Shoemaking in Street, Somerset. Utica: Sessions.

Tomkins, Alannah. 2015. Poverty, Kinship Support and the Case of Ellen Parker 1818-1827. In Entitlement and Dispute under the English Poor Laws. Edited by Peter Jones and Steven King. Cambridge: Cambridge Scholars Publishing, pp. 107-38.

Williams, Samantha. 2014. 'They lived together as Man and Wife': Plebeian cohabitation, illegitimacy, and broken relationships in London, 1700-1840. In Cohabitation and Non-Marital Births in England and Wales, 1600-2012. Edited by Rebecca Probert. London: Palgrave Macmillan, pp. 65-79.

Williams, Samantha. 2018. Unmarried Motherhood in the Metropolis, 1700-1850. Pregnancy, the Poor Law and Provision. Berlin/Heidelberg: Springer.

Wrightson, Keith. 1980. The nadir of English illegitimacy in the seventeenth century. In Bastardy and Its Comparative History. Studies in the History of Illegitimacy and Marital Nonconformity in Britain, France, Germany, Sweden, North America, Jamaica and Japan. Edited by P. Laslett, K. Oosterveen and R. Wall. Cambridge: Harvard University Press, pp. 177-91.

Wrigley, Edward Anthony. 1981. Marriage, Fertility and Population Growth in Eighteenth-Century England. In Marriage and Society: Studies in the Social History of Marriage. Edited by R. B. Outhwaite. New York: St. Martins Press, pp. 155-63.

Wrigley, Edward Anthony, R. S. Davies, James E. Oeppen, and Roger S. Schofield. 1997. English Population History from Family Reconstitution 1500-1837. Cambridge: Cambridge University Press, pp. 421-22.

(C) 2020 by the author. Licensee MDPI, Basel, Switzerland. This article is an open access article distributed under the terms and conditions of the Creative Commons Attribution (CC BY) license (http://creativecommons.org/licenses/by/4.0/). 